버섯폐배지의 발생량 조사 및 새송이, 느타리, 팽이 버섯 폐배지의 버섯종류별과 재배방식별의 물리화학적 특성 평가

김영일* . 배지선* . 정세형* . 안문환** . 곽완섭*

건국대학교 자연과학대학 생명자원환경과학부 축산학전공*, 충주시 농업기술센터**

\title{
Yield and Physicochemical Characteristics of Spent Mushroom (Pleurotus ryngii, Pleurotus osteratus and Ammulina velutipes) Substrates According to Mushroom Species and Cultivation Types
}

\author{
Y. I. Kim*, J. S. Bae*, S. H. Jung*, M. H. Ahn** and W. S. Kwak*
}

Animal Science, School of Life Resource and Environmental Sciences, College of Natural Sciences, Konkuk University, Danwol-dong 322, Chung-Ju, Chung-Buk, 380-701, Korea*,

Chungju Agricultural Technology Center**

\begin{abstract}
This study was conducted to determine the minimal yield of spent mushroom substrates (SMS) and physicochemical characteristics of Pleurotus ryngii, Pleurotus osteratus and Ammulina velutipes according to mushroom species and cultivation types. The annual yield of SMS in 2004 was minimally 1,670,182 M/T and 10.7-fold of the mushroom yield. The yield of SMS for Pleurotus ryngii, Pleurotus osteratus and Ammulina velutipes was $972,141 \mathrm{M} / \mathrm{T}$ and was $58.2 \%$ of the total yield of SMS. Data from the chemical analysis of totally 109 SMS samples revealed that bed type cultivation showed low NDF (65.2\%), high NFC $(12.7 \%)$ and high ash $(11.5 \%)$ contents $(\mathrm{P}<0.05)$, resulting in better nutritional characteristics compared with bottle or vinyl bag cultivation. In general, it was more desirable to classify SMS by cultivation types rather than by mushroom species for the effective use of SMS as an animal feed. Among cultivation types, SMS from bed type cultivation needed to be preferably used as feed.
\end{abstract}

(Key words : Spent mushroom substrate, Spent mushroom compost, By-product, Recycling, Feed)

\section{I. 서 론}

폐배지란 버섯을 생산하고 남은 버섯의 배지 를 말하며, 배지원료, 배합비 그리고 재배 방식 에 따라서 다양한 형태로 배출된다. 더욱이 버 섯의 종류, 재배방식 그리고 버섯을 생산하는 사람에 따라 원료의 종류와 배합비율은 차이가
있으며, 이로 인해 발생되는 폐배지 또한 성상 이 다양하다.

현재 폐배지는 여러 가지 방법으로 재활용되 고 있으며, 효율적 이용을 위하여 다양한 연구 가 이루어지고 있다. 구체적으로 유기농업과 원예농업에 있어서 퇴비로의 이용(Ehaliotis 등, 2005), 지렁이 생산용 배지로의 이용(Edwards

\footnotetext{
*본 연구는 2005년도 ARPC 연구비 지원에 의한 논문임

Corresponding author : Wan-Sup Kwak(Ph. D.) School of Life Resource and Environmental Sciences, College of Natural Sciences, Konkuk University, Chung-Ju, Chung-Buk, 380-701, Korea. Tel : +82-43-840-3521, e-mail : wsk@kku.ac.kr
} 
등, 1985), 수질개선에의 이용(Stark와 Williams, 1994; Anon, 1997; Groudev 등, 1999), 토양개량 제로의 이용(Semple과 Fermor, 1995; Semple 등, 1998; Fermor 등, 2000; Staments, 2001), 사료로 의 이용(Adamovic 등, 1998) 등이 있다.

특히 사료화 측면에서 버섯배지의 원료가 밀 짚(Kakkar 등, 1990; Adamovic 등, 1998), 볏짚 (Bakshi 등, 1985; Kakkar와 Dhanda, 1998), 사탕 수수 bagasse(Permana, 1990; Zadrazil와 Puniya, 1995) 등을 주원료로 하는 폐배지의 반추동물 의 사료로의 이용에 관한 연구가 보고된 바 있 다. 외국과 비교해서 국내에서 발생되는 새송 이, 느타리, 팽이 버섯 폐배지는 ash 함량이 $10 \%$ 내외로 낮으며, 영지, 표고, 상황, 만가닥 버섯 폐기목과 비교해서 분쇄과정이 필요 없 고, 발생량이 풍부하여 반추동물 사료로서의 이용 가치가 상대적으로 높을 것으로 보고하고 있다(배, 2006). 매년 버섯 생산량의 5 배에 해당 하는 폐배지가 발생한다는 보고(Williams 등, 2001; Semple 등, 2001)를 근거로 계산하면 2004 년도에 국내 버섯 생산량이 156,599 M/T(농림부, 2005)으로서 폐배지 발생량은 약 78만 M/T으로 추정 되나 이는 단지 비과학적인, 예측된 수치 일 뿐이다. 버섯 생산량의 5 배라는 수치는 버 섯재배환경이 상이한 외국에서 산출된 수치이 기 때문이다. 따라서 국내 환경에 맞게 버섯 종류별, 재배방식별 정확한 발생량이 산출되어 야 할 것이다.

폐배지를 가축사료로서 효과적으로 활용하기 위해서는 재배방식 및 버섯종류에 따른 폐배지 의 정확한 발생량 조사가 필수적으로 요구된 다. 배(2006)의 연구에서는 버섯 폐배지를 버섯 종류 및 배지 주원료에 의하여 분류하였으나 버섯 종류가 다른 폐배지 간에도 동일재배방식 에 따라서 물리 화학적 특성이 유사하여 쉽게 구분이 어려운 점과 현장 수준에서의 이용성을 고려한다면 폐배지를 재배 방식에 의해 분류하 는 것이 더 효과적인 방법일 수 있다.

따라서 본 연구는 버섯 폐배지의 효율적인 활용을 위하여 국내에서 발생되는 버섯 폐배지 의 최소한의 발생량을 재배방식과 버섯 종류별 로 정확하게 산출하고, 그리고 폐배지의 사료
로의 효율적인 활용을 위하여 새송이, 느타리, 팽이버섯농장 67곳을 현장 조사하고, 총 109점 의 시료를 채취하여 이들 폐배지의 물리 · 화 학적 특성을 체계적으로 평가하고자 실시하였 다.

\section{ㅍ. 재료 및 방법}

\section{1. 현장 조사 및 시료 채취}

지리적으로 우리나라 중부권에 속하는 충북 충주시, 청원군, 음성군, 괴산군, 진천군, 경북 문경시, 상주시 및 충남 부여시 일대에서 버섯 농장 67곳을 무작위로 현장 방문하여 버섯 종 류별과 재배 방식별로 새송이버섯 폐배지 40 점, 팽이버섯 폐배지 6점 및 느타리버섯 폐배 지 63점을 채취 하였으며, 총 109점의 폐배지 를 채취하였다.

모든 시료는 채취 전에 외관적 모습, 냄새, 배 지의 주원료 및 물리적 특성에 관하여 관찰 기 록하였으며, 대표적 시료를 확보하기 위하여 채 취 시에는 균상 재배의 경우 여러 위치에서 조 금씩 무작위로 채취하여 $1 \mathrm{~kg}$ 을 취하였으며, 병 재배 및 봉지 재배의 경우 각각의 봉지 또는 병 을 2 3개씩 철저히 혼합하여 $1 \mathrm{~kg}$ 정도를 채취하 여 비닐봉지에 밀봉한 다음 아이스박스에 넣어 실험실로 옮긴 후 $-20^{\circ} \mathrm{C}$ 냉동고(Deep Freezer, Ilshin Lab, Korea)에 분석시까지 저장하였다.

\section{2. 폐배지 발생량 조사}

배(2006)의 연구에 기초하여 사료적 가치가 높은 것으로 사료되는 새송이, 느타리, 팽이버 섯 폐배지는 전국적 또는 지역별 폐배지 발생 량을 도출하기 위해서 전국 수준에서 조사(농 림부, 2005)된 버섯 재배 면적에 면적당 배지 투입량, 원료배지의 수분 함량과 폐배지의 수 분 함량을 보정하는 것을 기초로 하여 하기한 공식을 이용하여 계산하였다.

폐배지발생량 $=$ 재배면적 $($ 평 $) \times$ 평당 배지원료 투입량 $\times \frac{\text { 투입원료의 건물\% }}{\text { 폐배지의 건물 } \%} \times 1$ 년 재배횟수 
새송이버섯, 팽이버섯은 병재배 방식에 의해 생산되며, 느타리버섯은 병, 봉지, 균상재배 방 식에 의해 생산된다. 2004특용작물생산실적(농 림부, 2005) 상의 재배 면적과 농가수가 재배방 식별 구분 없이 산출된 수치임에 따라 충주시 농업기술센터의 도움을 받아 재배방식별 분류 하여 각각 적용하였다. 팽이버섯의 병재배 경 우 2004 특용작물생산실적(농림부, 2005) 상의 재배 면적을 사용하였고, 느타리버섯 병재배는 재배방식별 분류된 수치를 적용하였다. 버섯종 류에 관계없이 병재배 방식의 평당 원료투입량 은 충북/경북 소재의 버섯농장을 방문하여 조 사한 결과인 평당 $2.64 \mathrm{~kg}$ 을 사용하였다. 새송 이 버섯은 농장의 규모가 대부분 영세하였으 며, 현장에서는 버섯배지가 들어있는 병을 구 입하여 자실체를 생산하고 있었다. 이에 따라 서 자실체 생육기간 18 20일 정도를 고려하여 년간 20회 정도 버섯을 생산하고 있었다. 조사 지역 중 새송이버섯 재배농가의 약 $80 \%$ 가 영 세하였으며, $20 \%$ 정도는 대규모 농장임을 고려 하여(data 미제시) 재배면적의 $80 \%$ 는 년간 20회 생산을, $20 \%$ 는 대규모 농장으로 년 중 공휴일 제외한 300회 생산을 발생량 계산에 적용하였 다. 느타리버섯 봉지재배의 경우, 평당 원료투 입량은 현장조사 결과인 평당 $1.9 \mathrm{~kg}$ 을 사용하 였다. 년 중 공휴일을 제외하고 250회 생산을 적용하여 산출하였다.

느타리버섯 균상재배의 경우 재배방식별 분 류된 전국 면적과 현장조사결과인 평당 원료투 입량 $50 \mathrm{~kg}$ 을 적용하였고, 춘기/추기 재배를 일 반적으로 실시함에 따라 년 2회 재배를 적용하 여 계산하였다. 양송이버섯은 느타리버섯 균상 재배와 같은 방식으로 계산하였다.

새송이버섯, 느타리버섯, 팽이버섯, 양송이버 섯 이외의 버섯 폐배지는 충주시 농업기술센터 의 자문을 받아서 신령버섯은 년간 1 회 재배하 여 평당 $50 \mathrm{~kg}$ 의 폐배지가 발생되는 것으로 계 산하였으며, 영지버섯과 상황버섯 그리고 기타 류에 속하는 표고버섯과 만가닥버섯은 폐골목 에서 재배가 되어 2 년 1 회 평당 $100 \mathrm{~kg}$ 의 폐배 지가 발생하는 것으로 하여 전체 발생량을 계 산하였다.

\section{3. 화학분석}

화학분석을 위하여 시료는 해동하여 $105^{\circ} \mathrm{C}$ 에 서 24시간 건조 후 Sample Mill(Cemotec, Tecator, Sweden)을 이용하여 $1 \mathrm{~mm}$ 크기로 분쇄하여 분 석에 이용하였다. Dry matter(DM), crude protein $(\mathrm{N} \times 6.25, \mathrm{CP})$, ether extract(EE)는 $\mathrm{AOAC}(1990)$ 의 방법에 따라, neutral detergent fiber(NDF), acid detergent fiber(ADF)는 Van Soest 등(1991) 의 방법에 따라 분석하였다. Organic matter $(\mathrm{OM})$ 는 100 -ash 값으로, hemicellulose는 $\mathrm{NDF}$ $-\mathrm{ADF}$ 값으로, nonfibrous carbohydrate(NFC)는 $100-(\mathrm{NDF} \%+\mathrm{CP} \%+\mathrm{EE} \%+\mathrm{ash} \%)$ 의 공식에 의해 구하였다. 비소화성 단백질(ADF-CP)은 acid detergent solution(ADS)에 녹인 후 여과물의 $\mathrm{CP}$ 를 측정하여 구하였다. True protein(TP)은 $5 \%$ trichloroacetic acid 용액에서 침전되는 양으로, non-protein nitrogen(NPN)은 $\mathrm{CP}$ 에서 $\mathrm{TP}$ 를 뺀 양 으로 구하였다. Lignin은 Van Soest 등(1991)의 방법에 따라 $\mathrm{ADS}$ 처리 후 $72 \%$ 농축 황산을 처 리하여 회화과정을 통해 측정하였고, cellulose는 $\mathrm{ADF}$-lignin 값으로 계산하였다.

\section{4. 통계분석}

통계 분석을 위하여 General Linear Model Procedure(SAS, 2002)를 이용하였으며, 재배방식별, 버섯종류별로의 평균간 비교를 위하여 Tukey's multiple range test를 이용하였다(SAS, 2002).

\section{III. 결과 및 고찰}

\section{1. 폐배지 발생량}

발생량이 많으면서 배 등(2006)의 연구에서 사료적 가치가 상대적으로 높은 것으로 판단된 새송이, 느타리, 팽이버섯의 재배방식별 폐배지 발생량은 전술한, 자체 개발한 공식에 의거하 여 계산하였으며, 그 결과는 Table 1에 제시되 어져 있다.

조사된 년간(2004년) 폐배지 발생량 972,141 $\mathrm{M} / \mathrm{T}$ 에 대한 지역별 발생량은 전남이 $27.5 \%$ 로 
Table 1. Calculated regional and total annual yields of spent mushroom substrates according to cultivation types ${ }^{1)}$

\begin{tabular}{|c|c|c|c|c|c|c|c|}
\hline \multirow[b]{2}{*}{ Province } & \multicolumn{4}{|c|}{ Bottle type } & \multirow{2}{*}{$\begin{array}{l}\text { Vynylbag } \\
\text { type }^{2)}\end{array}$} & \multirow[b]{2}{*}{ Bed type $^{2)}$} & \multirow{2}{*}{$\begin{array}{c}\text { Annual } \\
\text { total }\end{array}$} \\
\hline & $\begin{array}{c}\text { Pleurotus } \\
\text { eryngii }\end{array}$ & $\begin{array}{l}\text { Pleurotus } \\
\text { osteratus }\end{array}$ & $\begin{array}{c}\text { Flammulina } \\
\text { velutipes }\end{array}$ & Sum & & & \\
\hline & & & & $\mathrm{M} / \mathrm{T}$ & & int & $\ldots \ldots$ \\
\hline Gyeonggi & 7,845 & 16,728 & 35,749 & 60,322 & 41,670 & 15,537 & 117,529 \\
\hline Gangwon & & 9,402 & 3,742 & 13,144 & 7,001 & 37,954 & 58,099 \\
\hline Chungbuk & 2,307 & 8,653 & 9,774 & 20,734 & 5,208 & 19,120 & 45,062 \\
\hline Chungnam & 21,041 & 11,956 & 37,334 & 70,331 & 8,007 & 37,595 & 115,933 \\
\hline Jeonbuk & 14,297 & 11,496 & 43,603 & 69,396 & 3,940 & 15,380 & 88,716 \\
\hline Jeonnam & 67,433 & 27,911 & 114,227 & 209,571 & 28,619 & 28,964 & 267,154 \\
\hline Gyeongbuk & 27,737 & 7,632 & 34,391 & 69,760 & 14,427 & 23,048 & 107,235 \\
\hline Gyeongnam & 64,059 & 13,924 & 20,857 & 98,840 & 4,396 & 10,264 & 113,500 \\
\hline Jeju & 574 & 3,209 & & 3,783 & - & - & 3,783 \\
\hline Metropolis & 7,110 & 25,694 & 7,133 & 39,937 & 11,611 & 3,584 & 55,132 \\
\hline Total & 212,403 & 136,605 & 306,810 & 655,818 & 124,877 & 191,446 & 972,141 \\
\hline
\end{tabular}

1) Calculated on the basis of $\operatorname{KMAF}(2005)$.

2) Cultivation type of Pleurotus osteratus.

가장 많았으며, 경기, 충남, 경북, 경남이 $10 \%$ 수준이었으며, 강원, 충북, 제주, 광역시에서의 발생량은 $10 \%$ 이하 이었다.

병재배로 발생되는 폐배지는 팽이버섯의 경 우 원료 투입량의 1.5 배, 느타리 및 새송이버섯 은 원료투입량의 1.9 배가 발생되는 것으로 조 사되었다. 봉지재배는 원료 투입량의 2.0 배, 균 상재배는 2.8배(습물 기준)가 발생되었다. 새송 이버섯, 팽이버섯, 느타리버섯은 각각 ' 04 년에 $32,736 \mathrm{M} / \mathrm{T}, 32,769 \mathrm{M} / \mathrm{T}, 52,211 \mathrm{M} / \mathrm{T}$ (농림부, 2005) 이 생산되어 폐배지는 버섯생산량의 6.5, 9.4, 8.7배가 각각 발생된 것으로 나타났다. 이들 수 치는 현장에서 대략적으로 이용되는 수치인 5 배(Williams, 2001) 보다는 훨씬 높은 수치였다.

폐배지 중 사료적 가치가 상대적으로 높을 것으로 판단되는 느타리, 새송이, 팽이버섯 폐 배지의 재배방식별 발생비율에 있어서 전체 폐 배지 발생량 $972,141 \mathrm{M} / \mathrm{T}$ 중 $67 \%$ 가 병재배 방 식에 의해, $20 \%$ 가 균상재배 방식에 의해, $13 \%$ 가 봉지재배 방식에 의해 발생되고 있었다. 또
한 버섯종류에 따른 발생량의 비율은 느타리버 섯에 의해 $46 \%$ 가, 팽이버섯에 의해 $32 \%$ 가, 새 송이버섯에 의해 $22 \%$ 가 발생되고 있었다. 병재 배 방식에 의해 발생되는 폐배지는 외관적 성 상이 비슷하여 상호 구분이 어렵기 때문에 버 섯농가에서 발생되는 폐배지를 분류하는 것은 버섯의 종류 보다는 재배 방식에 의함이 더 효 과적인 분류 방법인 것으로 사료되었다. 전체 폐배지 발생량 $972,141 \mathrm{M} / \mathrm{T}$ 중 병재배 방식에 의해 가장 많이 발생되며, 이는 $67 \%$ 수준이었 다. 이중 $47 \%$ 가 팽이버섯에 의해, $32 \%$ 가 새송 이버섯에 의해, $21 \%$ 가 느타리버섯에 의해 발생 되었다. 새송이버섯과 팽이버섯은 병재배 방식 에 의해 발생되며, 느타리버섯은 병재배, 봉지 재배, 균상재배 모두에서 발생된다. 재배 방식 이 가장 다양한 느타리버섯은 전체 폐배지 발 생량 $972,141 \mathrm{M} / \mathrm{T}$ 의 $46 \%$ 를 차지하며, 이중 균 상재배에 의해 $42 \%$ 가, 병재배에 의해 $30 \%$ 가, 봉지재배에 의해 $28 \%$ 가 발생되었다.

재배방식별 년간 농가당 폐배지 발생량은 전 
체 느타리버섯 재배농가 8,004 농가 중 병재배 는 281 농가로 전체의 $3.5 \%$ 수준에 불과하나 농가 평균 폐배지 발생량은 년간 $486 \mathrm{M} / \mathrm{T}$ 으로 가장 많았으며, 가장 낮은 균상재배의 농가당 폐배지 발생량은 평균 $31 \mathrm{M} / \mathrm{T}$ 이었다. 따라서 병재배 방식이 가장 집약적인 재배 방식임을 알 수 있었다.

그 외에, 새송이, 느타리, 팽이버섯의 재배방 식별 재배 농가 및 농가당 폐배지 발생량에 있 어서 새송이 버섯과 팽이버섯은 전량 병재배에 의해 생산이 되는 점과 느타리버섯은 균상, 봉 지, 병재배에 의해 생산이 되는 점들을 고려한 다 하더라도 균상재배 농가가 6,266(68.6\%) 농 가로 가장 많으나 농가당 년간 $30.6 \mathrm{M} / \mathrm{T}$ 의 폐 배지가 발생되어 전체 평균인 $85.5 \mathrm{M} / \mathrm{T}$ 의 약 $1 / 3$ 수준이며, 병재배 방식 $464.1 \mathrm{M} / \mathrm{T}$ 의 $1 / 15$ 수 준으로 낮은 수치였다.

양송이버섯은 균상재배를 하며 이의 폐배지 는 년간 $657,509 \mathrm{M} / \mathrm{T}$, 신령버섯 폐배지는 2,147 $\mathrm{M} / \mathrm{T}$ 발생되는 것으로 계산되었으며, 폐골목에 서 생산되는 영지버섯 폐배지는 $16,839 \mathrm{M} / \mathrm{T}$, 상 황버섯 폐배지는 $13,453 \mathrm{M} / \mathrm{T}$ 및 기타로 분류된 표고와 만가닥버섯의 폐배지는 $8,093 \mathrm{M} / \mathrm{T}$ 으로 계산되었다. 사료적 가치가 상대적으로 높을 것으로 사료되는 느타리, 새송이, 팽이버섯에 의해 발생되는 폐배지 $972,141 \mathrm{M} / \mathrm{T}$ 와 그 이외 의 버섯에서 발생되는 폐배지 $698,041 \mathrm{M} / \mathrm{T}$ 을 더하면 년간 총 발생량은 $1,670,182 \mathrm{M} / \mathrm{T}$ 되는 것으로 조사되었다(Fig. 1). '04년도 폐배지 발
생량은 대략적으로 버섯 생산량인 156,599 M/T 의 10.7배 수준이었다. 이는 Williams 등(2001)이 보고한 5 배와는 2 배 이상의 차이가 있었다.

참고로, 폐배지 발생량은 투입원료와 발생 폐배지간의 수분 함량의 차이를 보정하여 계산 된 수치임으로 건물 손실은 고려되지 않았다는 점과 버섯농가에서 등록하지 않거나 축소신고 후 버섯을 재배하는 경우가 있다는 점, 그리고 새송이, 느타리, 팽이, 양송이 이외의 다른 버 섯의 발생량에 대하여서는 단순계산에 의해 산 출된 수치인 점 등을 고려한다면 제시된 모든 발생량의 수치는 최소치임을 고려하여야 할 것 이다.

\section{2. 폐배지의 외관적 및 물리적 특성}

폐배지의 외관적 특성은 버섯의 재배방식에 따라 차이가 많은 것으로 나타났다. 병재배의 경우 배출시 자동탈병기에 의해 폐배지가 병에 서 분리되어 주원료인 톱밥과 유사한 성상으로 배출되며 흰색 균사체가 관찰되었다. 봉지재배 의 경우 $600 \mathrm{ml}$ 정도의 원기둥 모양 비닐봉지 에 폐배지가 들어 있는 형태로 배출되며, 비닐 을 벗겨도 둥근 원기둥 모양을 유지하였다. 균 상재배의 경우에는 폐배지를 삽 등을 이용하여 균상에서 폐배지를 제거하기 때문에 마치 계란 찜과 같은 형태로 배출된다. 배지의 외형적 성 상은 재배방식에 따른 배지원료 조성에 의해 큰 영향을 받았으며, 배지 주원료는 폐배지의

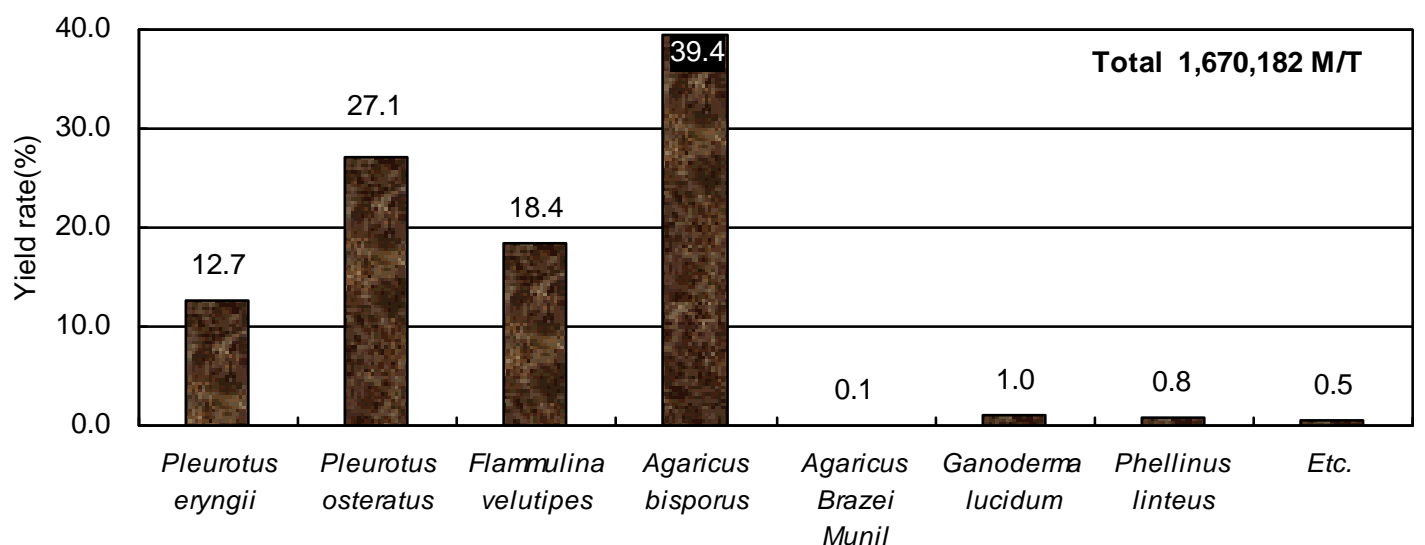

Fig. 1. Yield rates of spent mushroom substrates according to mushroom species in 2004. 
종류는 외관만으로도 톱밥인지 폐면인지 확인 이 가능하였다.

새송이버섯/느타리버섯 병재배의 경우 버섯 재배농가에서는 부피감을 목적으로 미송 또는 포플러 톱밥을 30 50\% 수준에서, 옥공이를 20 -30\% 수준에서 다양하게 사용하고 있었으며, 영양원으로 미강 또는 소맥피를 $10 \sim 20 \%$ 수준 에서 다양하게 사용하고 있었다. 사용되는 원 료 모두 톱밥의 색과 유사하기 때문에 병 재배 방식에 의해 발생되는 폐배지 간에는 외형적으 로 큰 차이는 없었다. 팽이버섯 폐배지의 경우 조사된 농가에서는 미송/포플러톱밥 $70 ~ 80 \%$, 미강 $20 \%$, 옥공이 $10 \%$ 수준에서 사용하고 있 었다. 봉지재배의 경우 조사된 농가에서는 톱 밥 $\quad 40 \sim 60 \%$, 면실피 $30 \sim 40 \%$, 면실박 $10 \sim$ $15 \%$, 비트펄프 $10 \sim 30 \%$ 수준에서 농가별로 다 양하게 사용하고 있었다. 균상재배의 경우 폐
면을 $100 \%$ 사용하는 농가가 대부분이었으며, 일부 농가에서 땅콩피를 $10 \%$ 수준에서 혼합하 여 사용하는 경우도 있었으며, 전통적인 방식 인 볏짚 $100 \%$ 를 사용하는 농가도 드물지만 있 었다. 그리고 각 재배방식에 따른 폐배지의 향 은 재배하는 버섯의 향과 유사하였다.

\section{3. 화학적 특성}

총 109 개의 버섯 폐배지를 버섯재배 방식에 따라 분류하여 제시한 화학적 조성은 Table 2 에 나타나 있다. 배 등(2006)의 연구에서는 총 48 개의 폐배지를 배지 주원료에 따라 분류하였 으며, 보고된 느타리버섯 재배 후의 톱밥주원 료 폐배지의 $\mathrm{NDF}, \mathrm{ADF}, \mathrm{CP}$ 함량은 본 연구의 봉지재배 방식 폐배지와 유사하였고, 폐면 주 원료 폐배지의 $\mathrm{NDF}, \mathrm{ADF}, \mathrm{CP}$ 는 본 연구의 균

Table 2. Chemical composition of spent mushroom substrates according to the cultivation type ${ }^{1)}$

\begin{tabular}{|c|c|c|c|c|}
\hline \multirow[b]{2}{*}{ Item } & \multicolumn{3}{|c|}{ Cultivation type } & \multirow[b]{2}{*}{$\mathrm{SE}$} \\
\hline & $\begin{array}{c}\mathrm{Bed}^{2)} \\
(\mathrm{n}=33)\end{array}$ & $\begin{array}{l}\text { Bottle } e^{3)} \\
(n=52)\end{array}$ & $\begin{array}{l}\text { Vinyl bag } \\
(n=24)\end{array}$ & \\
\hline & n.................... & n............. & c.................. & (n..... \\
\hline Neutral detergent fiber & $65.2^{\mathrm{b}}$ & $73.6^{\mathrm{a}}$ & $76.1^{\mathrm{a}}$ & 6.7 \\
\hline Acid detergent fiber & $62.6^{\mathrm{a}}$ & $55.0^{\mathrm{b}}$ & $65.4^{\mathrm{a}}$ & 8.2 \\
\hline Hemicellulose & $2.6^{\mathrm{C}}$ & $18.6^{\mathrm{a}}$ & $10.7^{\mathrm{b}}$ & 4.8 \\
\hline Cellulose & $44.4^{\mathrm{a}}$ & $35.8^{\mathrm{b}}$ & $40.9^{\mathrm{a}}$ & 8.7 \\
\hline Lignin & $18.2^{\mathrm{b}}$ & $19.1^{\mathrm{b}}$ & $24.4^{\mathrm{a}}$ & 5.3 \\
\hline Nonfibrous carbohydrate & $12.7^{\mathrm{a}}$ & $9.8^{\mathrm{b}}$ & $5.7^{\mathrm{c}}$ & 4.1 \\
\hline Crude protein & $9.7^{\mathrm{b}}$ & $8.1^{\mathrm{c}}$ & $11.5^{\mathrm{a}}$ & 2.0 \\
\hline True protein/CP & $66.2^{\mathrm{b}}$ & $61.6^{\mathrm{b}}$ & $74.2^{\mathrm{a}}$ & 11.4 \\
\hline Non-protein N/CP & $33.8^{\mathrm{a}}$ & $38.4^{\mathrm{a}}$ & $25.8^{\mathrm{b}}$ & 11.4 \\
\hline ADF-CP/CP & $49.0^{\mathrm{b}}$ & $36.9^{\mathrm{c}}$ & $58.5^{\mathrm{a}}$ & 10.7 \\
\hline Ether extract & $1.0^{\mathrm{b}}$ & $2.1^{\mathrm{a}}$ & $0.4^{\mathrm{c}}$ & 0.9 \\
\hline Crude ash & $11.5^{\mathrm{a}}$ & $6.4^{\mathrm{b}}$ & $6.3^{\mathrm{b}}$ & 3.2 \\
\hline Dry matter & $30.6^{\mathrm{b}}$ & $39.8^{\mathrm{a}}$ & $36.1^{\mathrm{a}}$ & 8.8 \\
\hline
\end{tabular}

\footnotetext{
a,b,c Means with different superscripts within the same row are significantly different $(\mathrm{P}<0.05)$.

1) Dry matter basis.

2) Culture ingredient was $100 \%$ cotton waste.

3) Culture ingredients were $30 \sim 80 \%$ sawdust, $10 \sim 20 \%$ rice bran and $10 \sim 30 \%$ corn _cob.

4) Culture ingredients were $40 \sim 60 \%$ sawdust, $10 \sim 30 \%$ beet plup, $10 \sim 15 \%$ cottonseed meal, and $30 \sim 40 \%$ cottonseed hulls.
} 
상재배 방식 폐배지의 성분과 유사하였다. 그 러나 톱밥주원료 폐배지는 본 연구의 병재배 폐배지의 $\mathrm{NDF}, \mathrm{CP}$ 와는 큰 차이가 없었으나, $\mathrm{ADF}$ 함량은 본 연구에서 다소 낮은 편이었다.

본 연구에서 폐배지의 NDF 함량은 65.2 $76.1 \%$ 수준 이었으며, 이는 정(2003)이 보고한 팽이버섯 폐배지의 $\mathrm{NDF} 73.4 \%$ 와 비슷한 수준 이었다. CP 함량과 ash 함량 또한 각각 $8.1 \%$ $11.5 \%, 6.3 \sim 11.5 \%$ 수준으로서 정(2003)이 보고 한 팽이버섯 폐배지의 CP $11.5 \%$, ash $8.3 \%$ 와 비슷한 수준이었다.

균상재배 폐배지는 병재배, 봉지재배 폐배지 보다 $\mathrm{NDF}$ 함량이 낮고 $(\mathrm{P}<0.05)$, ash 함량이 높 았으며 $(\mathrm{P}<0.05), \mathrm{NDF}$ 의 대부분이 $\mathrm{ADF}$ 로 구성 되어 있고, NFC 함량이 높고 $(\mathrm{P}<0.05)$, lignin 함 량이 낮은 $(\mathrm{P}<0.05)$ 특징이 있어서 사료적 가치 가 상대적으로 높을 것으로 사료되었다. 균상 재배 폐배지의 ash 함량이 가장 높은 것은 배 지 원료 조성에 기인하며, 병재배의 경우 ash 함량이 $3 \%$ 수준인 톱밥을 30 80\% 수준에서, ash $2 \%$ 수준의 옥공이를 20 30\% 수준에서 사 용하고, 봉지재배의 경우 톱밥을 $40 \sim 60 \%$ 수준 에서, ash 3\% 수준의 면실피를 30 40\% 수준 에서 사용하는 반면 균상재배에서는 ash $6.9 \%$ 수준의 폐면을 대부분의 농가에서 $100 \%$ 사용 하는 것에 기인하는 것으로 사료되었다. 봉지 재배 폐배지는 $\mathrm{CP}$ 와 $\mathrm{TP}$ 의 비율 또한 가장 높 은 $(\mathrm{P}<0.05)$ 특징이 있었으며, 이에 따른 비소화 성 단백질(ADF-CP)의 비율 또한 가장 높았다 $(\mathrm{P}<0.05)$. 병재배 폐배지는 $\mathrm{EE}$ 가 가장 높았으며 $(\mathrm{P}<0.05)$, 이는 배지의 원료에 $\mathrm{EE}$ 함량이 $19 \%$ 수준(data 미제시)인 미강이 10 20\%정도 함유 되는 것에 기인하는 것으로 사료되었다.

국내에서 발생되는 새송이, 느타리, 팽이 버 섯폐배지는 ash 함량이 6.3 11.5\% 수준으로 낮 아서 사료로의 이용성이 높을 것으로 사료되 나, 양송이버섯 폐배지의 경우 ash 함량이 $54.8 \%$ 수준(Table 미제시)으로서 사료로의 이용 이 어려울 것으로 사료되었다. 이란의 Fazaeli과 Talebian(2006)은 양송이버섯 배지에서 상층부의 흙을 제외하고도 폐배지의 ash 함량은 $35.1 \%$ 수준으로 여전히 높은 것으로 보고한 바 있다.
전반적으로 국내에서 발생되는 주요 버섯폐배 지는 섬유소(NDF, $\mathrm{ADF})$ 의 함량이 높고, $\mathrm{CP}$ 함 량은 낮으며, 비소화성 단백질(ADF-CP)의 함량 이 높은 특징이 있었다.

버섯 폐배지의 재배 방식에 따른 화학성분의 변이도는 Table 3에 제시되어져 있다. 재배방식 에 관계없이 $\mathrm{NDF}$ 함량의 변이도는 $7.7 \sim 12.3 \%$ 수준으로 예상보다 낮아서 동물사료의 섬유소 원으로 효과적으로 사용할 수 있을 것으로 판 단되었다. 전반적으로 균상재배 폐배지의 화학 성분(특히, $\mathrm{DM}, \mathrm{NDF}$, hemicellulose)은 병재배와 봉지재배 폐배지에 비해 변이도가 높은 편이었다. 균상재배는 느타리버섯 재배방식이며, Adamovic 등(1998)은 느타리버섯 재배기간에 따른 각 세 포벽 구성성분들의 함량이 배양기간에 따라서 감소하는 것으로 보고하였으며, 균상재배의 특 성상 배지에서 버섯 생산량이 저조하면 배지의 상태에 관계없이 폐상을 함으로 배지당 버섯 생산기간이 상이하게 되고 이로 인해 균사체에

Table 3. Coefficiency of variation in chemical composition of spent mushroom substrates according to the cultivation type $^{1)}$

\begin{tabular}{lrrr}
\hline \multicolumn{1}{c}{ Item } & $\begin{array}{r}\text { Bed } \\
(\mathrm{n}=33)\end{array}$ & $\begin{array}{c}\text { Bottle } \\
(\mathrm{n}=52)\end{array}$ & $\begin{array}{c}\text { Vinyl } \\
\text { bag } \\
(\mathrm{n}=24)\end{array}$ \\
\hline \hline Neutral detergent fiber & 12.3 & 7.7 & 9.0 \\
Acid detergent fiber & 13.6 & 16.9 & 6.6 \\
Hemicellulose & 111.9 & 32.3 & 37.2 \\
Cellulose & 27.6 & 21.0 & 8.6 \\
Lignin & 33.6 & 29.2 & 11.5 \\
Nonfibrous carbohydrate & 31.7 & 37.9 & 84.9 \\
Crude protein(CP) & 24.6 & 22.1 & 16.3 \\
$\quad$ True protein & 18.4 & 17.8 & 14.9 \\
$\quad$ Non-protein N & 36.0 & 28.6 & 42.8 \\
$\quad$ ADF-CP & 21.5 & 22.7 & 25.0 \\
Ether extract & 58.5 & 57.0 & 36.5 \\
Crude ash & 40.1 & 37.4 & 32.4 \\
Dry matter & 44.1 & 14.5 & 14.4 \\
\hline 1) Dry matter basis. & & &
\end{tabular}


의한 섬유소 분해 현상(Andrew와 Anita, 1995; Makela 등, 2002)에 차이를 발생시키고 결과적 으로 변이도에 영향을 미치게 되는 것으로 예 측된다. 또한 병재배나 봉지재배의 경우 버섯 배지 원료 및 배합비율이 농가마다 조금씩 상 이한 것도 변이도를 높이는 원인이 되었다.

버섯종류에 따른 폐배지의 화학적 조성은 Table 4에 제시되어져 있다. 새송이버섯(Pleurotus eryngii), 팽이버섯(Flammulina velutipes) 폐배지 는 Table 2에 제시된 병재배 폐배지와 대부분 의 성분이 비슷한 수준이었다. 이는 새송이버 섯과 팽이버섯이 전량 병재배에 의해 재배되기 때문이다. 본 연구의 팽이버섯 폐배지는 배 (2006) 등의 연구에서 팽이버섯 톱밥주원료 폐 배지와 대부분의 성분이 비슷한 수준이었으며, 정(2006)의 연구에서 팽이버섯 폐배지의 $\mathrm{NDF}$ 와 $\mathrm{ash}$ 는 비슷한 수준이었으나, $\mathrm{CP}$ 는 본 연구에서 다소 낮았다.

느타리버섯(Pleurotus osteratus) 폐배지는 Table 2 의 균상재배 폐배지와 비슷한 편이며, 느타리
버섯폐배지 63개 시료 중 33 개가 균상재배방식 이기 때문에 영향을 많이 받은 것으로 사료된 다. Table 2의 재배방식에 따른 분류에서 $\mathrm{NDF}$, lignin, ash의 성분이 재배방식에 따라 유의적 차이가 있었으나 $(\mathrm{P}<0.05)$, Table 4 의 버섯 종류 에 따른 분류에서는 버섯 종류에 따른 유의적 차이는 없었다 $(\mathrm{P}>0.05)$. 이런 차이는 버섯종류 가 달라도 재배방식이 같으면 배지의 조성이 비슷하다는 데에 원인이 있으며, 새송이버섯과 팽이버섯은 병재배에 의해서만 생산을 하지만 느타리버섯은 병, 봉지, 균상재배에 의해 생산 을 하기 때문에 버섯 종류별로 폐배지를 분류 하게 되면 재배방식에 따라 성상이 서로 다른 폐배지들이 모두 느타리버섯으로 분류가 되기 때문에 다른 버섯의 폐배지와도 유의적 차이가 없을 뿐만 아니라 느타리버섯 재배방식에 따라 다양한 특성을 가지고 배출되는 폐배지를 효과 적으로 분류할 수도 없다. 버섯폐배지를 분류 할 때는 버섯의 종류가 달라도 재배방식이 같 으면 폐배지의 성상이 비슷하다는 점, 전체 발

Table 4. Chemical composition of spent mushroom substrate according to the mushroom species1

\begin{tabular}{|c|c|c|c|c|}
\hline \multirow[b]{2}{*}{ Item } & \multicolumn{3}{|c|}{ Mushroom species } & \multirow{2}{*}{ SE } \\
\hline & $\begin{array}{c}\text { Pleurotus eryngii } \\
(\mathrm{n}=40)\end{array}$ & $\begin{array}{l}\text { Pleurotus osteratus } \\
(\mathrm{n}=63)\end{array}$ & $\begin{array}{l}\text { Flammulina velutipes } \\
(\mathrm{n}=6)\end{array}$ & \\
\hline & . & $\cdots \cdots$ &  & ?.... \\
\hline Neutral detergent fiber & 73.0 & 70.3 & 75.0 & 7.9 \\
\hline Acid detergent fiber & $53.3^{\mathrm{b}}$ & $63.9^{\mathrm{a}}$ & $56.4^{\mathrm{b}}$ & 7.8 \\
\hline Hemicellulose & $19.8^{\mathrm{a}}$ & $6.5^{\mathrm{b}}$ & $18.6^{\mathrm{a}}$ & 5.4 \\
\hline Cellulose & $35.0^{\mathrm{b}}$ & $42.8^{\mathrm{a}}$ & $35.8^{\mathrm{ab}}$ & 8.7 \\
\hline Lignin & 18.2 & 21.1 & 20.6 & 5.6 \\
\hline Nonfibrous carbohydrate & 10.8 & 9.5 & 6.9 & 4.7 \\
\hline Crude protein & $7.8^{\mathrm{b}}$ & $10.5^{\mathrm{a}}$ & $7.8^{\mathrm{b}}$ & 2.0 \\
\hline True protein/CP & $61.7^{\mathrm{ab}}$ & $69.4^{\mathrm{a}}$ & $55.1^{\mathrm{b}}$ & 11.5 \\
\hline Non-protein N/CP & $38.3^{\mathrm{ab}}$ & $30.6^{\mathrm{b}}$ & $44.9^{\mathrm{a}}$ & 11.5 \\
\hline ADF-CP/CP & $35.6^{\mathrm{b}}$ & $52.9^{\mathrm{a}}$ & $30.2^{\mathrm{b}}$ & 10.5 \\
\hline Ether extract & $2.1^{\mathrm{b}}$ & $0.7^{\mathrm{c}}$ & $3.5^{\mathrm{a}}$ & 0.7 \\
\hline Crude ash & 6.4 & 9.0 & 6.8 & 3.7 \\
\hline Dry matter & $38.7^{\mathrm{b}}$ & $33.5^{\mathrm{b}}$ & $47.5^{\mathrm{a}}$ & 8.9 \\
\hline
\end{tabular}

1) Dry matter basis.

a,b,c Means with different superscripts within the same row are significantly $\operatorname{different}(\mathrm{P}<0.05)$. 
생량 $972,141 \mathrm{M} / \mathrm{T}$ 의 $67 \%$ 가 병재배 방식에 의해 발생되며, 버섯종류별 비율에 있어서는 느타리 버섯이 $40 \%$ 로 가장 높은 비율을 차지하면서 재배방식이 다양하다는 점, 영양성분에 있어서 버섯종류에 따른 분류보다는 재배방식에 따른 분류에서 유의적 차이를 더 확실하게 볼 수 있 다는 점 등을 고려하면 폐배지를 버섯종류보다 는 재배방식에 의해 분류하는 것이 더 효과적 인 것으로 판단되었다. 향후 폐배지 종류별 동 물체내에서의 영양적 이용성은 대사 또는 사양 실험을 통해 확인하여야 할 것이다.

\section{IV. 요 약}

본 연구에서는 폐배지의 동물 사료로의 효율 적 이용을 위하여 국내에서 발생되는 폐배지의 최소한의 발생량을 버섯종류와 버섯재배 방식 에 따라 산출하고, 느타리, 새송이, 팽이 버섯 폐배지의 물리화학적 특성을 버섯종류별과 재 배방식별로 평가하고자 실시하였다. 2004년도 우리나라 폐배지 총 발생량은 $1,670,182 \mathrm{M} / \mathrm{T}$ 이 었다. 사료로의 이용가능성이 상대적으로 높을 것으로 예상되는 새송이버섯, 팽이버섯, 느타리 버섯 폐배지는 전체 발생량의 58.2\%인 972,141 $\mathrm{M} / \mathrm{T}$ 이 발생되었으며, 이중 재배방식별로는 병 재배에 의해 $67 \%$, 균상재배에 의해 $20 \%$, 봉지 재배에 의해 $13 \%$ 가 발생되었으며, 버섯 종류별 로는 느타리버섯 폐배지가 $46 \%$, 팽이버섯 폐배 지가 $32 \%$, 새송이버섯 폐배지가 $22 \%$ 발생되 었다. 버섯 재배방식별 폐배지의 물리화학적 특성에 있어서 균상재배 폐배지는 병재배와 봉 지재배 폐배지 보다 $\mathrm{NDF}$ 함량(65.2\%)이 낮고, $\mathrm{NFC}$ 함량(12.7\%)이 높은 특징이 있어서 $(\mathrm{P}<0.05)$, 사료적 가치가 상대적으로 높을 것으로 사료되 었다. 폐배지의 화학적 성분 변이도는 병 또는 봉지재배 방식보다 균상재배 방식에서 높은 편 이었으며, 전반적으로 섬유소(NDF) 함량의 변 이도는 예상보다 낮은 편이었다. 결과적으로 폐배지를 동물 사료로 이용 시 버섯종류에 따 라 분류하는 것보다는 재배방식에 따라 분류하 여 사용하는 것이 바람직하였으며, 사료영양적 측면에서 가치가 높은 균상재배 폐배지의 우선
적 이용이 권장된다.

\section{$\mathrm{V}$. 인 용 문 헌}

1. Adamovic, M., Grubi, G., Milenkovic, I., Jovanovi, R., Proti, R., Sretenovi, L. and Stoievi, L. 1998. The biodegradation of wheat straw by Pleurotus ostreatus mushrooms and its use in cattle feeding. Animal Feed Science Technology 71:357-362.

2. Andrew, S. B. and Anita, M. J. 1995. The recovery of lignocellulose-degrading enzymes from spent mushroom compost. Bioresoruce Tech. 54:311-314.

3. Anon. 1997. Cleaning up rivers with mushroom compost. Biocycle 138(12):6.

4. AOAC. 1990. Official Methods of Analysis(15th Ed.). Association of official Analytical Chemists, Washington D.C.

5. Bakshi, M. P. S., Gupta, V. K. and Langar, P. N. 1985. Acceptability and nutritive evaluation of Pleurotus harvested spent wheat straw in buffaloes. Agricultural Wastes 13:51-58.

6. Edwards, C. A., Burrows, I., Fletcher, K. E. and Jones, B. A. 1985. The use of earthworms for composting farm wastes. pp. 229-242. In: J. K. R. Gasser (ed). Composting of agricultural and other wastes. Elsevier Applied Science Publishers, London.

7. Ehaliotis, C., Georgios, I. Z. and Karavitis, P. 2005. Residues and by-products of olive-oil mills for root-zone heating and plant nutrition in organic vegetable production. Scientia horticulturae 106:293-308.

8. Fazaeli, H. and Talebian, A. R. M. 2006. Spent wheat straw compost of agaricus bisporus mushroom as ruminant feed. AJAS. 19(6):845-851.

9. Fermor, T., Watts, N., Duncombe, T., Brooks, R., McCarthy, A., Semple K. and Reid, B. 2000. Bioremediation: use of composts and composting echnologies. Mushroom Science 15:833-839.

10. Governot, T. R. 1997. Best practices for environmental protection in the mushroom farm community. Commonwealth of Pennsylvania. PA, USA.

11. Groudev, S. N., Bratcova, S. G. and Komnitsas, K. 
1999. Treatment of alters polluted with radioactive elements and heavy metals by means of a laboratory passive system. Mineral Engineering 12(3):261-270.

12. Kakkar, V. K. and Dhanda, S. 1998. Comparative evaluation of wheat and paddy straws for mushroom production and feeding residual straws to ruminants. Bioresource Technology 66(2):175-177.

13. Kakkar, V. K., Garach, H. S., Dhanda, S. and Makkar, G. S. 1990. Mushroom harvested spent straw as feed for buffaloes. Indian Journal of Animal Nutrition 7:267-272.

14. Makela, M., Galkin, S., Hatakka, A. and Lundell, T. 2002. Production of organic acids and oxalate decarboxylase in lignin-degrading white rot fungi. Enzyme and microbial technology 30:542-549.

15. Permana, I. G. 1990. The Evaluation of Nutritive Value of Sugarcane Bagasse as Ruminant Feed. Diploma work. Bogor Agricultural University. Bogor, Indonesia.

16. Semple, K. T., Watts, N. U. and Fermor, T. R. 1998. Factors affecting the mineralization of (U14C) benzene in spent mushroom substrate. FEMS Microbiology Letters 164(2) :317-321.

17. Semple, K. T. and Fermor, T. R. 1995. The bioremediation of enobiotic-contamination by composts and associated microflora. Mushroom Science 14(2): 917-924.

18. Semple, K. T., Reid, B. J. and Fermor, T. R. 2001. Impact of composting strategies on the treatment of soils contaminated with organic pollutants. Environmental pollution 112:269-283.
19. Staments, P. 2001. Mycova: Helping the ecosystem through mushroom cultivation. http://www.fungi. com/bioremediation/index.html (June 29, 2001)

20. Stark, L. R. and Williams, F. M. 1994. The roles of spent mushroom substrate for the mitigation of coal mine drainage. Compost Science and Utilization 2(4):84-94.

21. Williams, B. C., McMullan, J. T. and McCahey, S. 2001. An initial assessment of spent mushroom compost as a potential energy feedstock. Bioresource Technology 79:227-230.

22. Zadrazil, F. and Puniya, A. K. 1995. Studies on the effect of particle size on solid-state fermentation of sugarcane bagasse into animal feed using white-rot fungi. Bioresource Technology 54:85-87.

23. 농림부(KMAF). 2005. 2004특용작물생산실적. 농 림부.

24. 배지선, 김영일, 정세형, 오영균, 곽완섭. 2006. 느타리, 새송이 및 팽이버섯 폐배지의 반추동물 조사료원으로의 사료 영양적 가치평가. 한국동물 자원과학회지 48(2):237-246.

25. 배지선. 2006. 버섯 폐배지의 반추동물 조사료원 으로서의 사료 영양적 가치에 대한 기초 평가. 건국대학교 석사학위 논문.

26. 정근기. 2003. 한우 경쟁력 제고 기술개발. 농림 부 최종보고서.

(접수일자 : 2006. 11. 28. / 채택일자 : 2007. 2. 5.) 